\title{
Perbandingan Kualitas Hidup antara Pasien DRESS (Drug Reaction With Eosinophilia and Systemic Symptom) dan SJS (Stevens Johnson Syndrome)/TEN (Toxic Epidermal Necrolysis) akibat Penggunaan Obat di RSUP Dr. Sardjito Yogyakarta
}

\author{
Ratna Septi Tristiana*1, Dyah Aryani Perwitasari², Sri Awalia Febriana² \\ ${ }^{1}$ Fakultas Farmasi, Universitas Ahmad Dahlan, Yogyakarta \\ ${ }^{2}$ Departemen Dermatologi dan Venereologi RSUP Dr. Sardjito Yogyakarta \\ ${ }^{2}$ Fakultas Kedokteran dan Keperawatan, Universitas Gadjah Mada, Yogyakarta \\ *E-mail : tristianaratna@yahoo.co.id
}

\begin{abstract}
Drug Reaction with Eosinophilia and Systemic Symptoms (DRESS) is a severe drug reaction on the skin, idiosyncratic, which symptoms include fever, rash and multi-organ failure due to drug induction. Stevens Johnson Syndrome (SJS) / Toxic Epidermal Necrolysis (TEN) is the outcome of keratinocytes deaths, leading to separation of the skin area in the layer between dermal and epidermal, causing blistered skin. The difference between SJS / TEN is seen through the wide area of epidermis released (epidermolysis), namely: $<10 \%$ for SJS, $10-30 \%$ for SJS overlapping TEN and > 30\% for TEN. It is considered necessary to conduct research on the quality of life of patients suffering from DRESS and SJS / TEN. This research was conducted to determine differences in patient's quality of life between DRESS and SJS / TEN due to drug use. The method used in this non-experimental observational study was carried out with a cross sectional design. Research samples were patients with DRESS and SJS / TEN based on inclusion criteria. Secondary data were retrieved from medical record. Data regarding patients' quality of life were collected prospectively using the EQ5D questionnaire. From the quality of life assessment issued using the EQ5D questionnaire, a significance value of $\rho<0.05$ was obtained in all domains. Significance value $(\rho)$ in all domains claimed to have different qualities between DRESS and SJS / TEN related to drug use. The EQ-5D VAS analysis resulted in an average value of $76.3636 \pm 14.48988$ in DRESS patients and $56.7647 \pm 26.45414$ in SJS / TEN patients. This value proves that DRESS patients have a better quality of life compared to SJS / TEN patients. Significance value ( $\rho$ ) at EQ5D VAS $\rho<0.05$. The significance value ( $\rho$ ) on EQ5D VAS states about the difference in quality of life in question between DRESS and SJS / TEN patients regarding drug use. Patients' quality of life assessed using EQ5D showed a significant difference between patients with DRESS and SJS / TEN patients impacts of drug consumption.
\end{abstract}

Keywords: Quality of Life, DRESS (Drug Reaction with Eosinophilia and Systemic Symptom, SJS (Stevens Johnson Syndrome), TEN (Toxic Epidermal Necrolysis), impacts of drug consumption.

\begin{abstract}
ABSTRAK
Drug Reaction with Eosinophilia and Systemic Symptoms (DRESS) merupakan reaksi obat berat pada kulit, idiosinkratik yang ditandai dengan demam, ruam dan kegagalan multiorgan akibat induksi obat. Stevens Johnson Syndrome (SJS) / Toxic Epidermal Necrolysis (TEN) adalah kelainan kulit berupa lepuh pada perbatasan dermal dan epidermal yang diakibatkan karena kematian keratinosit. Perbedaan antara SJS/TEN dilihat berdasarkan luas area epidermis yang terlepas (epidermolisis), yaitu: <10\% untuk SJS, 10-30\% untuk SJS overlap TEN dan >30\% untuk TEN. Dari gejala yang ditimbulkan maka perlu dilakukan penelitian tentang penilaian kualitas hidup pasien yang mengalami DRESS dan SJS/TEN akibat penggunaan obat. Metode yang digunakan pada penelitian non-experimental observasional ini dilakukan dengan rancangan cross sectional. Pemilihan subjek penelitian menggunakan populasi pasien yang mengalami DRESS dan SJS/TEN berdasarkan kriteria inklusi. Pengambilan data sekunder melalui rekam medis secara retrospektif dan penilaian kualitas hidup menggunakan kuesioner EQ5D secara prospektif. Dari penilaian
\end{abstract}


kualitas hidup yang dinilai menggunakan kuesioner EQ5D, didapatkan nilai signifikansi $\rho<0,05$ pada semua domain. Nilai signifikansi $(\rho)$ pada semua domain menyatakan bahwa terdapat perbedaan kualitas hidup yang bermakna antara pasien DRESS dan SJS/TEN akibat penggunaan obat. Untuk hasil analisis EQ5D VAS, didapatkan nilai rata-rata $76,3636 \pm 14.48988$ pada pasien DRESS dan 56,7647 \pm 26.45414 pada pasien SJS/TEN. Nilai tersebut membuktikan bahwa pasien DRESS memiliki tingkat kualitas hidup lebih baik bila dibandingkan dengan pasien SJS/TEN. Nilai signifikansi pada EQ5D VAS $\rho<0,05$. Nilai signifikansi $(\rho)$ pada EQ5D VAS menyatakan bahwa terdapat perbedaan kualitas hidup yang bermakna antara pasien DRESS dan SJS/TEN akibat penggunaan obat. Penilaian kualitas hidup menggunakan kuesioner EQ5D menunjukkan adanya perbedaan kualitas hidup yang signifikan pada pasien DRESS dan SJS/TEN akibat penggunaan obat.

Kata kunci: Kualitas hidup, DRESS (Drug Reaction with Eosinophilia and Systemic Symptom, SJS (Stevens Johnson Syndrome), TEN (Toxic Epidermal Necrolysis), akibat penggunaan obat.

\section{Pendahuluan}

Kemajuan dalam bidang farmasi dan meningkatnya penggunaan obat-obatan menyebabkan semakin banyaknya kejadian efek samping obat kutan (Adverse Cutaneous Drug Reactions) ACDRs yang tidak diharapkan. Salah satu efek samping obat yang sering terjadi adalah (Drug Reaction with Eosinophilia and Systemic Symptoms) DRESS dan (Stevens Johnson Syndrome) SJS / (Toxic Epidermal Necrolysis) TEN. DRESS yang juga dikenal dengan Drug-Induced Hypersensivity Syndrome (DIHS) merupakan reaksi obat berat pada kulit, idiosinkratik yang ditandai dengan demam, ruam dan kegagalan multiorgan akibat dari induksi obat. Sindrom ini jarang terjadi, onset penyakit lambat dan reaktivasi herpesvirus-6 dapat terjadi selama perjalanan penyakit. Patogenenesis DRESS melibatkan berbagai faktor yang saling berinteraksi meliputi: pajanan obat, ketidakmampuan obat dalam detoksifikasi metabolit, predisposisi genetik, interaksi obat, predisposisi penyakit, reaktivasi infeksi virus laten, respon imun terhadap metabolit obat dan respon imun terhadap reaktivasi virus [1].

Selain DRESS, efek samping obat yang sering terjadi adalah (Stevens Johnson Syndrome) SJS / (Toxic Epidermal Necrolysis) TEN. SJS/TEN adalah kelainan kulit berupa lepuh pada perbatasan dermal dan epidermal yang diakibatkan karena kematian keratinosit. SJS/TEN ditandai dengan adanya erosi pada mukosa dan makula purpura yang meluas, disertai dengan tanda Nikolsky positif. Perbedaan antara SJS/TEN dilihat berdasarkan luas area epidermis yang terlepas (epidermolisis), yaitu: $<10 \%$ untuk SJS, 10-30\% untuk SJS overlap TEN dan > $30 \%$ untuk TEN dikategorikan TEN [2].

Obat yang paling sering dilaporkan dapat menyebabkan DRESS adalah karbamazepin, allopurinol, sulfasalazin, fenobarbital, lamotrigin, NSAID, captopril, CCB, mexiletine, fluoxetine, dapsone, terbinafine, metronidazole, minosiklin dan obat anti HIV yaitu nevirapin dan raltegravir [2]. Dalam penelitian yang dilakukan oleh Wong et al. (2016), menyebutkan bahwa obat-obatan yang paling sering menyebabkan SJS/TEN antara lain allopurinol, beberapa golongan antibiotik termasuk sulfonamid, golongan antikonvulsan seperti karbamazepine, obat anti HIV dan beberapa obat antiinflamasi non-steroid (NSAID) [3].

Meskipun SJS/TEN jarang terjadi, mereka yang sembuh mengalami stres psikologis dan ketakutan setelah mengalami reaksi yang berpotensi mengancam jiwa ini. Hal ini akan mempengaruhi sikap mereka terhadap penggunaan obat di masa depan. Misalnya, seorang pasien dengan infeksi berulang yang pernah mengalami SJS/TEN akibat menggunakan antibiotik betalaktam, akan sangat berhati-hati apabila mendapatkan terapi antibiotik kembali untuk selanjutnya [4].

Kualitas hidup menurut World Health Organization (WHO) adalah persepsi seseorang dalam konteks budaya dan norma yang sesuai dan berlaku di tempat tinggal orang tersebut yang berkaitan dengan tujuan, harapan, standar dan kepedulian selama hidupnya. Kualitas hidup seseorang merupakan fenomena yang multidimensional. Pengukuran kualitas hidup bertujuan untuk memilih terapi yang memberikan efek optimal. Kualitas hidup juga dapat digunakan dalam proses monitoring untuk melihat luaran terapi serta menentukan kesehatan sekelompok pasien untuk mengevaluasi kualitas pelayanan yang diberikan. Dengan mempelajari kualitas hidup pasien, diharapkan dapat digunakan untuk membantu memperbaiki kualitas terapi dan tujuan terapinya [5].

Penelitian yang dilakukan oleh Nogueira et al. (2003), mengatakan bahwa penilaian kualitas hidup pada pasien SJS/TEN menggunakan kuesioner SF-36 memberikan hasil bahwa terdapat masalah pada domain ketidaknyamanan yang menyebabkan gangguan psikologis, sosial dan ekonomi yang besar selama kurang lebih 30 tahun. Hal ini terjadi pada usia produktif individu, sehingga menyebabkan pasien merasa sangat cemas dan depresi [6].

Pada saat ini, di Indonesia belum terdapat penelitian tentang kualitas hidup pada pasien yang mengalami DRESS dan SJS/TEN. Berdasarkan review beberapa artikel di atas, dapat diambil kesimpulan bahwa penelitian kualitas hidup pada 
pasien DRESS dan SJS/TEN akibat penggunaan obat sangat penting dilakukan di Indonesia, terutama untuk mengetahui pengaruh efek samping obat tersebut terhadap kualitas hidup pasien yang dihasilkan. Terkait masalah kualitas hidup, dapat diukur menggunakan beberapa kuesioner diantaranya SF-36, WHOQOL, EQ5D dan lain sebagainya. Pada penelitian ini, peneliti memilih untuk menggunakan kuesioner EQ5D dikarenakan kuesioner ini lebih mudah digunakan dan dipahami oleh berbagai kalangan masyarakat.

\section{Bahan dan Metode Penelitian}

\subsection{Bahan}

Pada penelitian ini menggunakan 2 jenis instrumen yang berbeda. Instrumen yang pertama berupa Case Report Form (CRF) di bagian Instalasi Catatan Medik (ICM) untuk mengumpulkan data sekunder yang diambil dari catatan rekam medis dan catatan medis pendukung lainnya yang meliputi nomor medical record, nama, tanggal masuk rumah sakit (MRS), tanggal keluar rumah sakit (KRS), usia, alamat, nomor telepon, diagnosa, obat yang menyebabkan ACDRs, riwayat alergi dan luaran klinis pasien ketika keluar rumah sakit pada pasien DRESS dan SJS/TEN di RSUP Dr. Sardjito Yogyakarta secara retrospektif.

Data yang sudah terkumpul akan dilakukan pemilihan melalui kriteria inklusi dan eksklusi untuk kemudian dilakukan penelitian lanjutan secara prospektif menggunakan instrumen yang kedua yaitu kuesioner EQ5D yang diisi oleh pasien yang datanya telah diambil melalui rekam medis sebelumnya. Kuesioner EQ5D berisi tentang 5 dimensi yang mencakup tentang mobilitas, perawatan diri, kegiatan sehari-hari, rasa sakit/ketidaknyamanan dan kecemasan/depresi yang dirasakan oleh pasien. Pengisian kuesioner EQ5D oleh pasien yang mengalami DRESS dan SJS/TEN memiliki 5 kategori tingkatan respon pada masing-masing domain. Tingkat respon 1 menunjukkan no problem (tidak ada masalah), tingkat respon 2 menunjukkan slight problems (sedikit bermasalah), tingkat respon 3 menunjukkan moderate problems (cukup bermasalah), tingkat respon 4 menunjukkan severe problems (sangat bermasalah) dan tingkat respon 5 menunjukkan extreme problems (amat sangat bermasalah). Dari 5 kategori tersebut kemudian dilakukan skoring menggunakan index value versi Indonesia untuk menghasilkan 2 kategori kualitas hidup baru yaitu: nilai 1 = tidak bermasalah dan nilai $2=$ bermasalah [7].
Pengambilan data pasien pertama di bagian instalasi catatan medik (ICM) berdasarkan "Lembar Permintaan Catatan Medis Pasien di RSUP DR. Sardjito tahun 2014-2019" dengan kode diagnosa ICD 10 L.27.0 dan L.27.1" untuk pasien DRESS sebanyak 29 pasien. Untuk pasien SJS/TEN dengan kode diagnosa ICD 10 L.51.1 sebanyak 52 pasien.

\begin{tabular}{|c|c|}
\hline $\overrightarrow{0}$ & $\begin{array}{l}7 \text { data pasien DRESS tidak masuk kriteria inklusi: } \\
\text { Nomor telepon dan alamat pasien tidak terdokumentasi ( } 2 \\
\text { pasien) } \\
\text { Pasien meninggal dunia ( } 2 \text { pasien) } \\
\text { Pasien menolak untuk menjadi subjek penelitian ( } 2 \text { pasien) } \\
\text { Alamat pasien tidak terjangkau ( } 1 \text { pasien) }\end{array}$ \\
\hline & $\begin{array}{l}22 \text { data pasien DRESS memenuhi kriteria inklusi, yang } \\
\text { kemudian dilakukan pengambilan data kualitas hidup } \\
\text { menggunakan instrumen kedua yaitu kuesioner EQ5D. }\end{array}$ \\
\hline & $\begin{array}{l}18 \text { data pasien SJS/TEN tidak masuk kriteria inklusi: } \\
\text { - Nomor telepon dan alamat pasien tidak terdokumentasi } \\
\text { ( } 4 \text { pasien) } \\
\text { - Pasien meninggal dunia ( } 9 \text { pasien) } \\
\text { - Pasien mengalami SJS/TEN tetapi tidak disebabkan oleh } \\
\text { penggunaan obat ( } 1 \text { orang) } \\
\text { - Nomor telepon pasien tidak dapat dihubungi (1 pasien) } \\
\text { - Pasien menolak untuk menjadi subjek penelitian (3 } \\
\text { pasien) }\end{array}$ \\
\hline & $\begin{array}{l}34 \text { data pasien SJS/TEN memenuhi kriteria inklusi, } \\
\text { yang kemudian dilakukan pengambilan data kualitas } \\
\text { hidup menggunakan instrumen kedua yaitu kuesioner } \\
\text { EQ5D. }\end{array}$ \\
\hline
\end{tabular}

Jumlah pasien DRESS dan SJS/TEN di RSUP Dr. Sardjito Yogyakarta selama tahun 2014-2019, baik pasien rawat jalan maupun rawat inap adalah 81 pasien yang terbagi dalam 29 pasien DRESS dan 52 pasien SJS/TEN. Pasien DRESS dan SJS/TEN yang akan dijadikan subjek dilakukan seleksi menggunakan kriteria inklusi dan eksklusi. Dari 29 pasien DRESS, didapatkan 2 data pasien tidak lengkap, 2 pasien meninggal dunia, 2 pasien menolak untuk menjadi subjek dan 1 pasien dengan alamat yang tidak dapat dijangkau, sehingga terdapat 22 subjek dengan DRESS. Dari 52 pasien dengan SJS/TEN, didapatkan 4 data yang tidak lengkap, 9 pasien meninggal dunia, 1 pasien mengalami SJS/TEN bukan karena penggunaan obat, 1 pasien tidak dapat dihubungi dan 3 pasien menolak untuk menjadi subjek, sehingga terdapat 34 subjek dengan SJS/TEN. Hal ini sesuai dengan penelitian terbaru di Amerika yang dilakukan oleh (Wolfson et al, 2018), dimana prevalensi DRESS sebesar 2,3\% dari 1.000 pasien per tahun. Sedangkan menurut penelitian yang dilakukan oleh Velasco-Tirado et al. (2018), insiden SJS/TEN yang terjadi di beberapa negara Eropa seperti Perancis dan Jerman adalah 1-4 penduduk untuk TEN dan 1-3 penduduk untuk SJS dari total 106 penduduk setiap tahunnya [8]. 


\subsection{Metode Penelitian}

Penelitian non-experimental observasional ini dilakukan dengan rancangan cross sectional. Analisis data pada variabel yang diteliti dilakukan dengan pendekatan statistik analisis deskriptif, analisis analitik dan multivariat dengan menggunakan bantuan software SPSS (Statistical product and Service Solutions) version 22 for windows.

Data tentang jumlah pasien yang mengalami DRESS dan SJS/TEN akibat penggunaan obat digabungkan dengan data skoring kuesioner EQ5D yang telah diisi oleh pasien menggunakan index value versi Indonesia dan disajikan dalam bentuk kategori baru beserta persentasenya. Untuk analisis analitik menggunakan uji $t$ independent analisis yang digunakan untuk menentukan perbedaan kualitas hidup pada pasien DRESS dan SJS/TEN akibat penggunaan obat apabila data terdistribusi normal (jika $\rho>0,05$ ). Untuk data analisis yang tidak terdistribusi normal (jika $\rho<0,05$ ), metode statistik yang digunakan adalah uji non parametrik yang selanjutnya dilakukan analisis statistik Mann Whitney untuk mengetahui perbedaan pada kedua kelompok sampel.

\section{Hasil dan Pembahasan}

\subsection{Gambaran EQ5D dari Pasien DRESS dan SJS/TEN}

Penilaian kualitas hidup menggunakan kuesioner EQ5D terdiri dari 5 domain yang saling berkaitan satu dengan yang lain. Domain mobilitas pada kuesioner EQ5D merupakan domain yang menggambarkan kemampuan berjalan pasien pada saat mengalami DRESS dan SJS/TEN. Kemampuan berjalan ini dapat dinilai dari tingkat kesulitan pasien dalam berjalan. Kualitas hidup pasien yang dinilai dari domain perawatan diri dapat dilihat dari kemampuan pasien dalam kegiatan mandi dan berpakaian secara mandiri dalam kehidupan sehari-hari. Untuk domain kegiatan yang biasa dilakukan dapat dilihat dari tingkat kesulitan pasien dalam melakukan kegiatan seperti bekerja, belajar, mengerjakan pekerjaan rumah tangga, kegiatan keluarga, bersantai atau berekreasi. Pada domain rasa sakit (nyeri) atau ketidaknyamanan yang diakibatkan DRESS dan SJS/TEN dinilai dari tingkatan rasa sakit (nyeri) yang dirasakan oleh pasien terhadap gejala yang ditimbulkan pada DRESS dan SJS/TEN. Penilaian kecemasan atau depresi yang terdapat dalam kuesioner EQ5D untuk pasien dengan DRESS dan SJS/TEN dinilai dari tingkat kecemasan atau depresi atau kesedihan yang dirasakan pasien akibat dari efek ACDRs yang terjadi, lamanya terapi dan keterlibatan organ lain yang menyertai.

Penilaian kualitas hidup pasien dengan DRESS dan SJS/TEN pada domain mobilitas menunjukkan hasil yang berbeda secara bermakna $(\rho=0,012)$. Pada domain mobilitas, pasien DRESS lebih baik dari pasien SJS/TEN dimana, $14(63,6 \%)$ pasien bermasalah dan $8(36,4 \%)$ pasien tidak bermasalah pada DRESS, sedangkan $30 \quad(88,2 \%)$ pasien bermasalah dan $4(11,8 \%)$ pasien tidak bermasalah pada SJS/TEN. Untuk domain perawatan diri, penilaian kualitas hidup pasien dengan DRESS dan SJS/TEN menunjukkan hasil yang berbeda secara bermakna ( $\rho=$ 0,000). Pada domain perawatan diri, pasien DRESS lebih baik dari pasien SJS/TEN dimana $13(59,1 \%)$ pasien bermasalah dan 9 (40,9\%) pasien tidak bermasalah pada DRESS, sedangkan pada SJS/TEN $33(97,1 \%)$ pasien bermasalah dan $1(2,9 \%)$ pasien tidak bermasalah. Pada domain kegiatan yang biasa dilakukan, penilaian kualitas hidup antara pasien DRESS dan SJS/TEN menunjukkan hasil yang berbeda secara bermakna $(\rho=0,000)$. Pada domain ini, pasien DRESS lebih baik dari pasien SJS/TEN, dimana terdapat $11(50,0 \%)$ pasien bermasalah dan 11 $(50,0 \%)$ pasien tidak bermasalah pada DRESS, sedangkan pada SJS/TEN terdapat $33(97,1 \%)$ pasien bermasalah dan 1 $(2,9 \%)$ pasien tidak bermasalah. Untuk penilaian kualitas hidup pasien dengan DRESS dan SJS/TEN pada domain rasa sakit atau ketidaknyamanan didapatkan hasil yang berbeda secara bermakna $(\rho=0,000)$. Pada domain rasa sakit atau ketidaknyamanan, pasien DRESS lebih baik dari pasien SJS/TEN, dimana $20(90,9 \%)$ pasien bermasalah dan 2 $(9,1 \%)$ pasien tidak bermasalah pada DRESS, sedangkan pada SJS/TEN $33(97,1 \%)$ pasien bermasalah dan $1(2,9 \%)$ pasien tidak bermasalah. Pada domain kecemasan atau depresi pasien dengan DRESS dan SJS/TEN menunjukkan hasil yang berbeda secara bermakna $(\rho=0,000)$. Untuk domain kecemasan atau depresi, pasien DRESS lebih baik dari pasien SJS/TEN, dimana $13(59,1 \%)$ pasien bermasalah dan $9(40,9 \%)$ pasien tidak bermasalah pada DRESS, sedangkan pada SJS/TEN $30(88,2 \%)$ pasien bermasalah dan $4(11,8 \%)$ pasien tidak bermasalah.

Dari analisis kuesioner EQ5D, didapatkan hasil bahwa terdapat perbedaan kualitas hidup secara bermakna $(\rho<$ 0,05 ) pada pasien DRESS dan SJS/TEN akibat penggunaan obat. Pasien DRESS memiliki kualitas hidup yang lebih baik pada semua domain bila dibandingkan dengan pasien SJS/TEN. Hal ini kemungkinan terjadi karena pasien SJS/TEN memiliki gejala yang lebih parah bila dibandingkan dengan pasien DRESS, sehingga menyebabkan kualitas hidup yang dihasilkan lebih buruk. Menurut Zavala et al. (2018), pasien dengan SJS/TEN ditandai dengan adanya nekrosis dan pelepasan epidermis yang ekstensif (epidermolisis) [9]. Gejala ini menyebabkan pasien SJS/TEN memiliki tingkat kesulitan yang lebih tinggi untuk melakukan aktivitas sehari-hari dan rasa sakit yang dirasakan akibat pelepasan epidermis (epidermolisis) akan terasa lebih parah. Penelitian yang pernah dilakukan oleh Nishikaku et al. (2016), dimana orang yang sembuh dari SJS/TEN akan mengalami komplikasi emosional dan fisik yang parah serta gangguan kualitas hidup yang berhubungan dengan kesehatan yang memerlukan tindak medis jangka panjang [10]. 
Tabel 1

Kualitas Hidup Pasien DRESS dan SJS/TEN dari Domain-Domain pada Kuesioner EQ5D

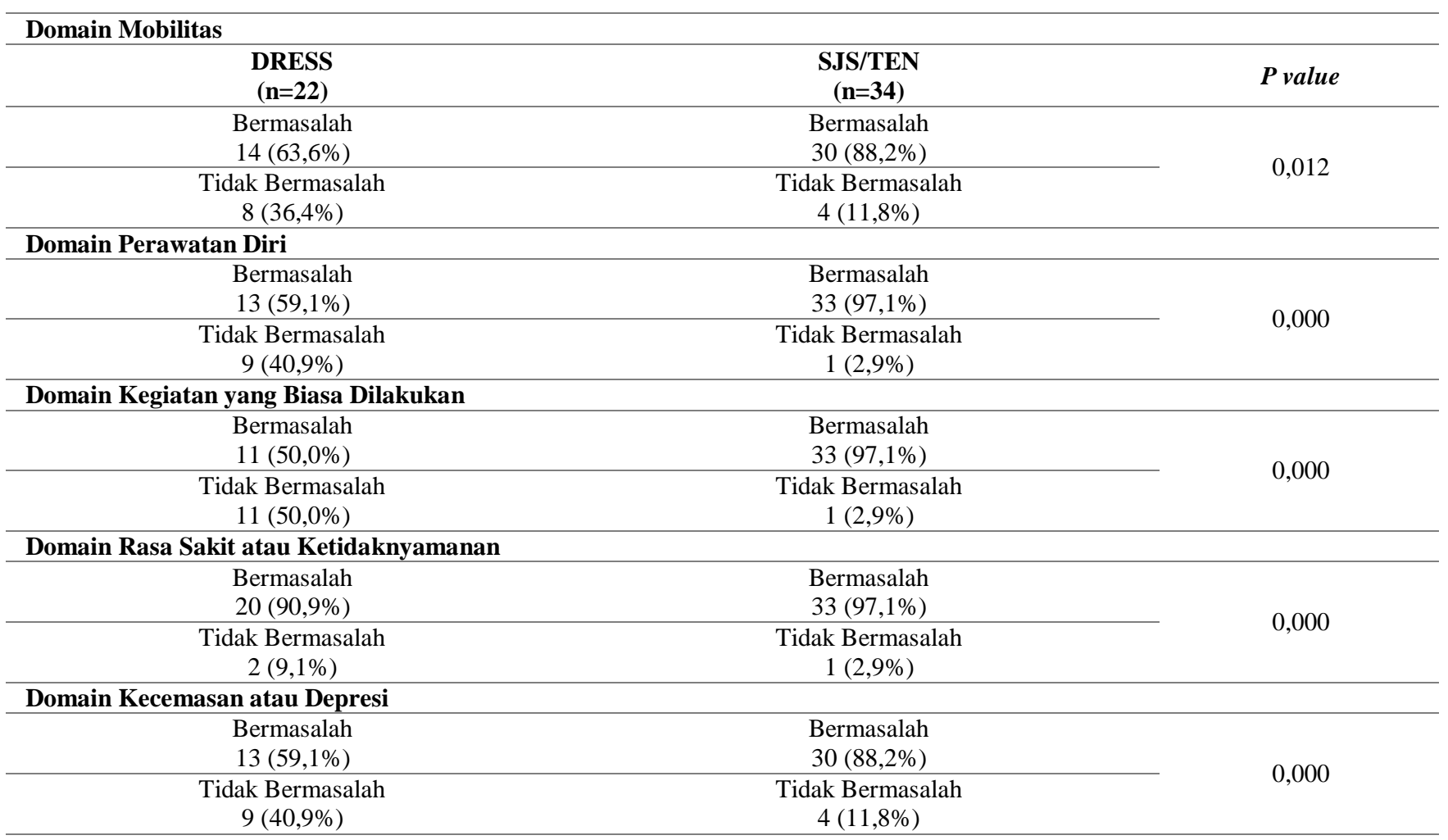

Keterangan: n, jumlah pasien; DRESS, drug reaction with eosinophilia and systemic symptom; SJS, stevens johnson syndrome; TEN, toxic epidermal necrolysis; $\rho$ value, nilai signifikansi.

Tabel 2

VAS Scale Pasien DRESS dan SJS/TEN

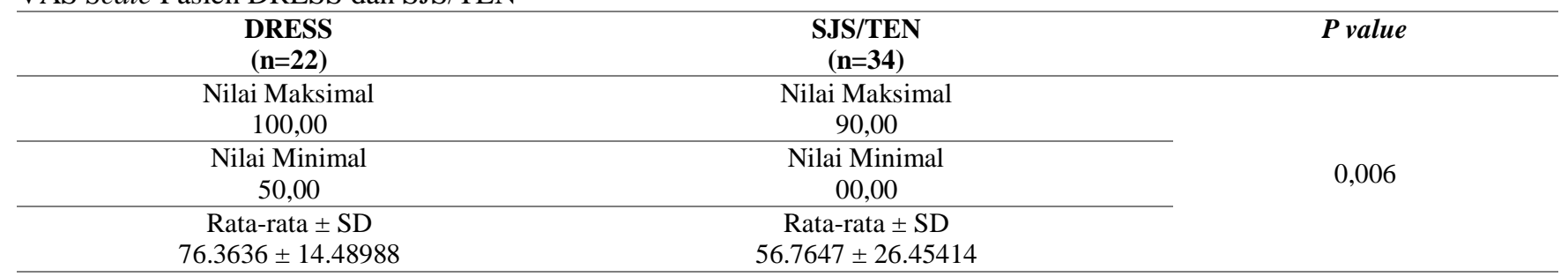

Keterangan: n, jumlah pasien; VAS, visual analogue scale; SD, standar deviasi; DRESS, drug reaction with eosinophilia and systemic symptom; SJS, stevens johnson syndrome; TEN, toxic epidermal necrolysis; EQ5D, euro quality of life 5 domain.

Gejala DRESS biasanya diawali dengan demam tinggi $38-40^{\circ} \mathrm{C}$ dan persisten, diikuti oleh ruam kulit, kemudian terjadi limfadenopati, faringitis dan keterlibatan sistemik. Edema wajah yang sering kali dikenali sebagai angioedema merupakan gejala khas untuk sindrom ini. Lesi kulit dalam bentuk ruam makulopapular dapat meluas menjadi eritroderma. Gejala ini awalnya muncul pada bagian wajah dan ekstremitas atas yang selanjutnya terjadi edema pada wajah yang menonjol. Hepatitis dan nekrosis hepatik merupakan penyakit penyerta pada $50 \%$ kasus pasien yang mengalami DRESS. Keterlibatan organ ginjal (interstitial nephritis), paru-paru (pneumonitis) dan hipotiroidisme terjadi dalam $10 \%$ kasus yang dilaporkan. Rhabdomyolysis berat, miopati dan pankreatitis juga telah dilaporkan.
Neutropenia, trombositopenia, agranulositosis dan anemia hemolitik juga dapat terjadi [11]. Meskipun pada pasien DRESS sering ditemukan adanya keterlibatan multiorgan seperti hepar, paru-paru, ginjal dan kelainan darah, pasien DRESS pada penelitian ini pasien merasa tidak terganggu dan masih bisa melakukan aktivitasnya sehari-hari.

\subsection{Gambaran EQ5D VAS Scale dari Pasien DRESS dan SJS/TEN}

EQ-5D VAS mencatat penilaian responden terhadap kesehatannya menggunakan skala analog visual yang berbentuk vertikal dan memiliki skala 0 hingga 100. Titik akhir ditandai dengan "best imaginable health state" (status 
kesehatan terbaik yang dapat dibayangkan) yang ditunjukkan dengan skala 100 dan "worst imaginable health state" (status kesehatan terburuk yang dapat dibayangkan) yang ditunjukkan dengan skala [7].

Uji normalitas yang dilakukan pada data kualitas hidup yang dinilai menggunakan kuesioner EQ5D VAS didapatkan hasil bahwa nilai normalitas data pada hasil kuesioner ini tidak terdistribusi normal $(\rho=0,00)$. Dari hasil analisis EQ5D VAS, pada pasien DRESS terdapat subjek yang kualitas hidupnya mencapai nilai maksimal 100,00 dan nilai minimal 50,00, sehingga didapatkan nilai rata-rata 76,3636 \pm 14.48988, sedangkan pada pasien SJS/TEN, subjek hanya mencapai nilai maksimal 90,00 dan nilai minimal 00,00, sehingga didapatkan nilai rata-rata 56,7647 \pm 26.45414 , dari hasil ini menunjukkan bahwa pasien DRESS memiliki status kesehatan lebih baik bila dibandingkan dengan pasien SJS/TEN. Dari analisis EQ5D VAS, didapatkan hasil bahwa terdapat perbedaan kualitas hidup secara bermakna $(\rho=$ 0,006) pada pasien DRESS dan SJS/TEN akibat penggunaan obat.

\section{Kesimpulan}

Berdasarkan penelitian yang telah dilakukan, didapatkan kesimpulan bahwa terdapat perbedaan kualitas hidup yang bermakna antara pasien DRESS dan SJS/TEN akibat penggunaan obat. Hal ini dibuktikan dari nilai signifikansi ( $\rho)$ yang didapatkan pada masing-masing domain $<0,05$. Sedangkan untuk EQ5D VAS Scale didapatkan nilai signifikansi $\rho=0,006$. Dari hasil analisis EQ5D VAS, didapatkan nilai rata-rata kualitas hidup 76,3636 \pm 14.48988 pada pasien DRESS dan $56,7647 \pm 26.45414$ pada pasien SJS/TEN. Nilai tersebut membuktikan bahwa pasien DRESS memiliki tingkat kualitas hidup lebih baik bila dibandingkan dengan pasien SJS/TEN.

\section{Ucapan Terimakasih}

Ucapan terima kasih kepada para pegawai dibagian instalasi catatan medik (ICM) RSUP Dr. Sardjito Yogyakarta yang telah membantu kelancaran pengambilan dan pelengkapan data penelitian.

\section{Daftar Pustaka}

[1] Tas, S., Simonart, T., Ben M'Rad, M., Leclerc-Mercier, S., Blanche, P., Franck, N., Rozenberg, F., Fulla, Y., Guesmi, M., Rollot, F., Dehoux, M., Guillevin, L., Moachon, L., M., A., J., K., L., L.-M., Mehrholz, D., Urban, A. E., Herstowska, M., ... da Silva, G. A. R. (2017). Severe cutaneous adverse drug reactions. Pan African Medical Journal, 5(4), 1-7. https://doi.org/10.3390/ijms18061243

[2] Cacoub, P., Musette, P., Descamps, V., Meyer, O., Speirs, C., Finzi, L., \& Roujeau, J. C. (2011). The DRESS syndrome: A literature review. American Journal of Medicine, 124(7), 588597. https://doi.org/10.1016/j.amjmed.2011.01.017

[3] Wong A, Malvestiti AA, \& Hafner Mde F. (2016). StevensJohnson syndrome and toxic epidermal necrolysis: a review. Revista Da Associação Médica Brasileira, 62(5), 468-473. https://doi.org/10.1590/1806-9282.62.05.468
[4] Thong, B. Y.-H. (2013). Stevens-Johnson syndrome / toxic epidermal necrolysis: an Asia-Pacific perspective. Asia Pacific Allergy, $3(4), \quad 215$. https://doi.org/10.5415/apallergy.2013.3.4.215

[5] Lamborn, K. R. (1996). Kathleen R. Lamborn, PhD Department of Neurological Surgery University. 548-549.

[6] Nogueira, R., Franca, M., Lobato, M. G., Belfort, R., Souza, C. B., \& Gomes, J. Á. P. (2003). Qualidade de vida dos pacientes portadores de síndrome de Stevens-Johnson. Arquivos Brasileiros de Oftalmologia, 66(1), 67-70. https://doi.org/10.1590/s0004-27492003000100013

[7] EuroQol, van Reenen, M., \& Janssen, B. (2015). EQ-5D-5Luserguide 2015. April. https://euroqol.org/wpcontent/uploads/2016/09/EQ-5D-5L_UserGuide_2015.pdf

[8] Velasco-Tirado, V., Alonso-Sardón, M., Cosano-Quero, A., Romero-Alegría, Á., Sánchez-los Arcos, L., López-Bernus, A., Pardo-Lledías, J., \& Belhassen-García, M. (2018). Lifethreatening dermatoses: Stevens-johnson syndrome and toxic epidermal necrolysis. Impact on the Spanish public health system (2010-2015). PLoS ONE, 13(6), 1-12. https://doi.org/10.1371/journal.pone.0198582

[9] Zavala, S., O’Mahony, M., Joyce, C., \& Baldea, A. J. (2018). How Does SCORTEN Score? Journal of Burn Care and Research, 39(4), 555-561.

[10] Nishikaku, A. S., Gompertz, O. F., \& Disciplina, D. D. I. (2016). Major emotional and physical complications among survivors of Stevens-Johnson syndrome and toxic epidermal necrolysis. Journal of the American Academy of Dermatology, 74(5), AB61. https://doi.org/10.1016/j.jaad.2016.02.242

[11] Verma, R., Vasudevan, B., \& Pragasam, V. (2013). Severe cutaneous adverse drug reactions. Medical Journal Armed Forces India, $69(4), \quad 375-383$. https://doi.org/10.1016/j.mjafi.2013.01.007 